with various large ants, especially with Formica exsectoides, subsericea, etc., but very often with termites also, particularly in rotten trunks where they insert themselves between the passages of their victims.

I cannot finish this short notice of the habits of the North American ants that I have observed thus far, without thank- ing most sincerely my good friends and colleagues Dr. Ad. Meyer of Worcester, Dr. Murphy of Morganton, and Dr. Faisons of Faisons, to whose aid, hospitality and inexhaustible kindness I owe all that I have discovered. Now I go to visit the able American myrmecologist Mr. Pergande at Washington and thence return to Europe.

\title{
LIFE HISTORIES OF NORTH AMERICAN GEOMETRIDAE. - XXIV.
}

BY HARRISON G. DYAR, WASHINGTON, D. C.

Eois inductata Guen. The moth from which these eggs were obtained was in very poor condition and the larvae died before pupation, but I believe that the determination is correct and that there are no more larval stages. There is no previous description of this larva.

Egg. Long and nearly cylindrical, less in one diameter but not with any flattened surface; one end first a little bulging, then tapering to a round blunt point, wedge shaped from side view, the other end (micropylar) roundedly truncate. About eighteen longitudinal ribs, fluted at the joinings of the faint regular cross-striae which form square cells. Ribs diminishing by a few before the ends; micropylar end coarsely irregularly reticulate. Pearly white, looking beaded from the fluted ribs. Length .9 , width $.4 \times \cdot 3 \mathrm{~mm}$. The next day turned pink, shading to red at the truncate end.

Stage $I$. Head rounded, free, slightly bilobed, luteous, faintly mottled with brown; width $.3 \mathrm{~mm}$. Body slender, whitish, a rather broad, even, brown-gray dorsal band, separated on joints 2 to 4 into four diffuse lines, but soon merging into a single, broad dorsal band to joint 13 ; a broad subventral band, the pair separate. Tubercles pale, nearly obsolete; setae short, dusky with small enlarged tips. Feet pale; segments finely, about 2o-annulate. Anal flap pale. Segments scarcely enlarged centrally, uniform, smooth. After feeding turned greenish by transparency.

Stage II. Head round, scarcely bilobed, free; whitish, a white stripe on the face of each lobe, containing an isolated brown dot opposite middle of clypeus; many brown dots filling the median suture and apex of clypeus, also on the outer side of the white band; labrum pale; ocelli and tips of antennae brown-black; width $.4 \mathrm{~mm}$. Body moderately slender, smooth, normal, segments, numerously (about 20) annulate, but not distinctly ; setae short, black, rather coarse. Dorsum broadly dark brown, cut near its edge by a linear, slightly flexuous, pale yellowish subdorsal line, most distinctly at the ends and in incisures; sides pale green; a broad subventral band, colored like the dorsal one and slightly intensified at tubercle vii on each segment. Venter pale green rather narrowly. Cervical shield more reddish than the rest of the dorsum. Feet all pale.

Stage III. Head rounded, not bilobed, 
held out flat, free from joint 2 ; antennae rather large, divergent, straight; white with broad bands of brown mottlings, one on side of lobe and one next the median suture; suture itself brown as also the clypeal suture above; antennae black tipped; width $.6 \mathrm{~mm}$. Body moderate, segments about 30 -annulate, rather obscurely. Dorsum broadly brown, pulverulent, cut by narrow pale subdorsal line and on joints 2 to 5 by a dorsal line also. Shields concolorous, the anal plate pale at the sides. Subventral fold white, slightly yellowish. A broad subventral purple-brown band, emphasized below the spiracle by a darker patch; a nearly contiguous pale line below this band; venter narrowly white. Feet pale outwardly; setae short, black; tubercles minute.

Stage IV. Head white with brown dotted bands as before; width $.9 \mathrm{~mm}$. Body moderate, uniform, finely annulate. Dorsum dark brown, a fine white subdorsal line continuing the white of head; a paler brown lateral band in part contiguous to a still paler suprastigmatal one. Subventral fold white, a trace yellowish. A geminate subventral pale brown band, the upper half containing a nearly black dot below and before the spiracle. Venter not broadly whitish. Feet pale, the abdominal ones faintly brownish marked. No discolorous shields.

Stage $V$. Head erect, rounded, higher than wide, scarcely bilobed, antennae distinct; whitish with a brown shade, black dottings on each side from ocelli to vertex and between the lobes over the median suture; sutures of clypeus dark; width I.I $\mathrm{mm}$. Body slender, the segments moderately drawn out, the central ones about 25annulate, uniformly, annulet I somewhat larger. Whitish, dorsum pulverulently brown shaded, forming a dark geminate dorsal line, diffuse outwardly, followed by a pale subdorsal line, on the abdomen faintly, but on thorax and joint 5 distinctly edged by dark dottings. A whitish band on subventral fold; a vinous brown spot below it a little in front of the spiracle, distinct on joints 5 to 7 , faint on 8 and 9. Feet pale or a little brownish dotted, the anal ones elongate triangular. Tubercles minute, dark; setae short, dark, slightly enlarged before tip. Spiracles brown rimmed. There are some secondary setae present, forming about twenty hairs in all on each side of a segment, all alike in size and color. Most of the extra ones are subdorsal in a continuation of the line of $i$ and ii and subventral posterior.

Food plant unknown. The larvae fed on rag weed and clover. Moth from Washington, D. C. Eggs June I, last larval stage July I, but all died soon after without pupating.

A NeW USE for AN ovipositor. - A female Deidamia inscripta emerged in one of $\mathrm{my}$ boxes and in some way injured the first two legs on one side. After two or three days I noticed that when the moth hung from the lace over the top of the box it clung with the remaining legs, and thrust its ovipositor up through a mesh of the lace bending its tip forward so that it hesd like a bent finger. In this position the moth rested for many hours daily. Caroline G. Soule.

\section{A. SMITH \& SONS, 146-148 WILLIAM ST., Now York.

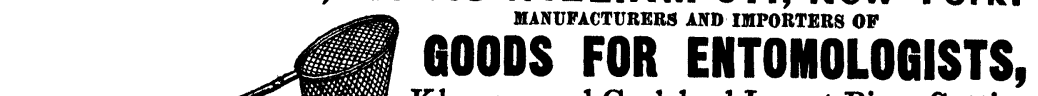 Klaeger and Carlsbad Insect Pins, Setting
Boards, Folding Nets, Locality and
Soldine
Special Labels, Forceps, Sheet Cork, Etc.
Other articles are being added, Send for List.}

Subscribers to Psyche in arrears will confer a favor by prompt payment of bills. 

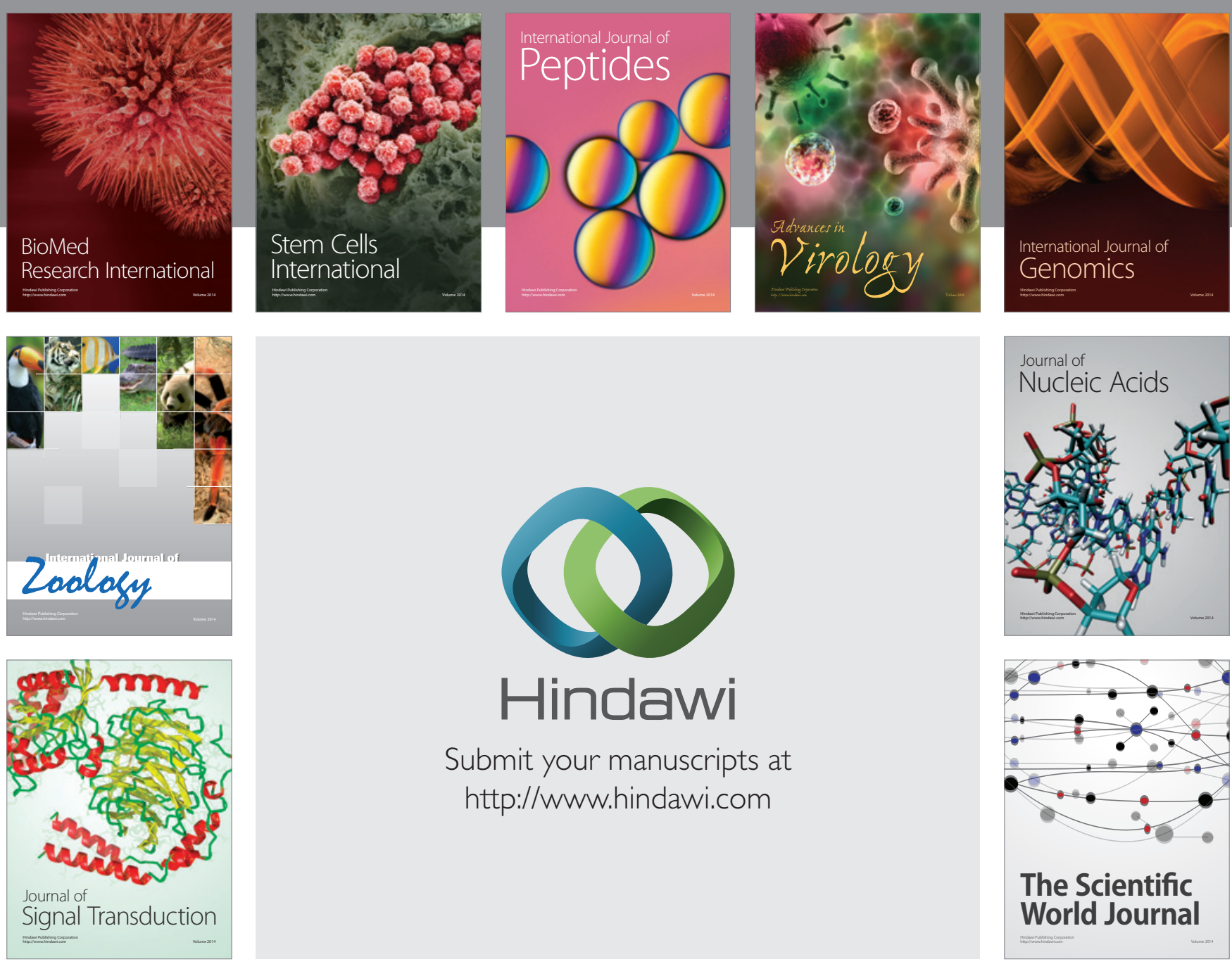

Submit your manuscripts at

http://www.hindawi.com
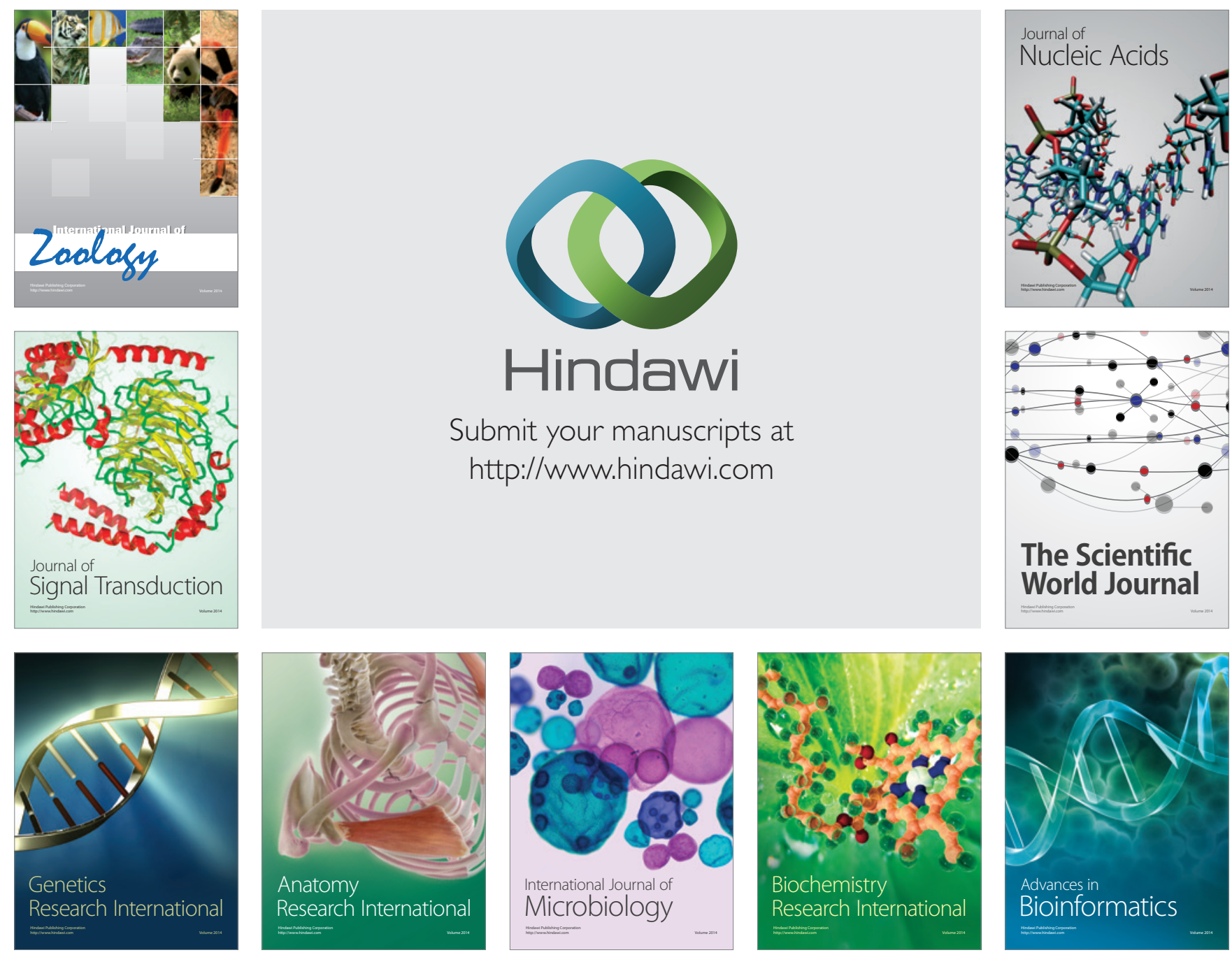

The Scientific World Journal
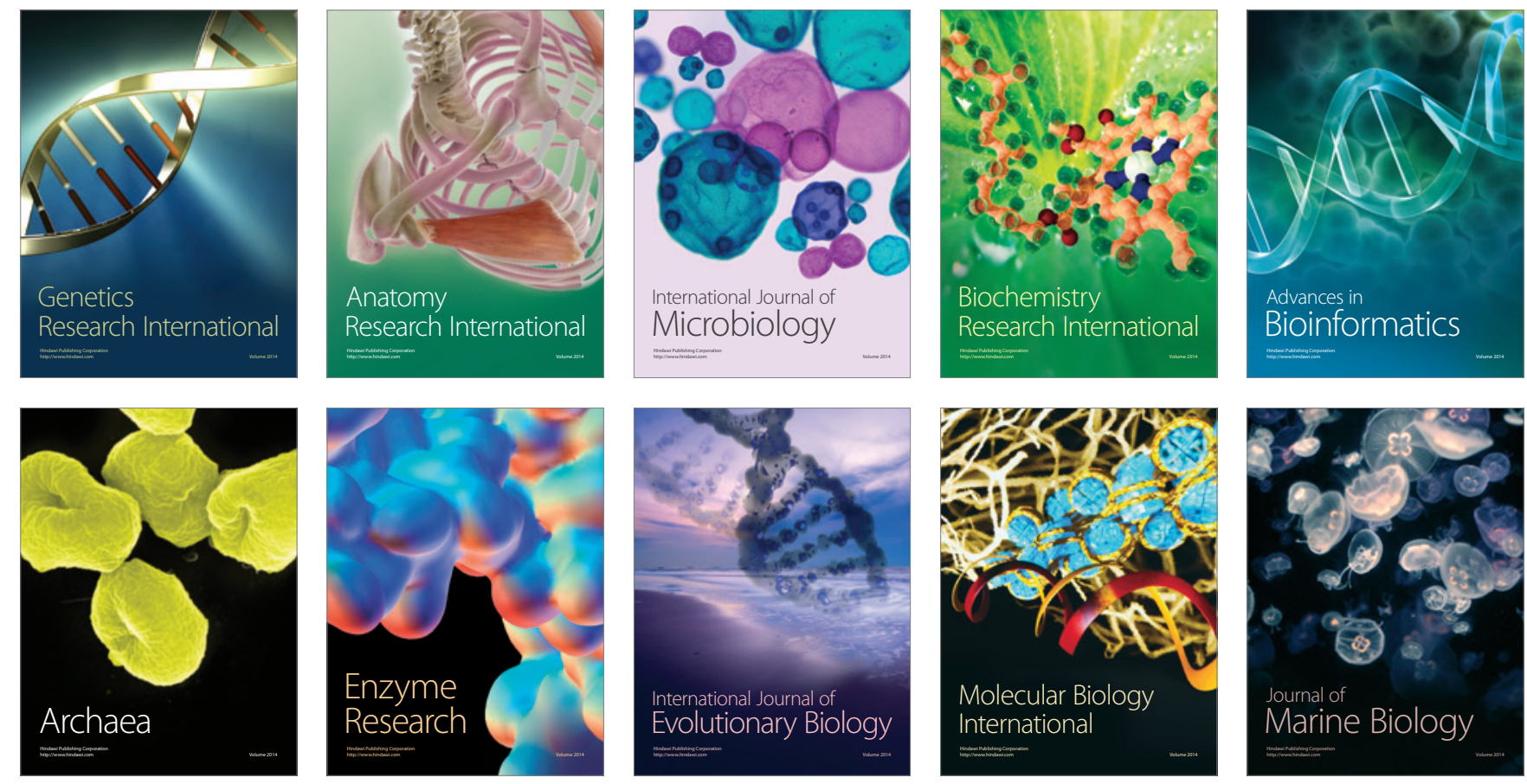